TINJAUAN

\title{
IMBUHAN BUATAN : SOLUSI UNTUK MENGATASI MASALAH KEKURANGAN AIRTANAH DI CEKUNGAN BANDUNG
}

\section{Nyoman Sumawijaya}

\begin{abstract}
ABSTRAK Analisa prospek penerapan imbuhan buatan menggunakan air cucuran atap untuk mengatasi permasalahan defisit airtanah di Cekungan Bandung dilakukan berdasarkan aspek kebutuhan, adanya sumber air dan adanya dukungan kebijakan. Penurunan muka airtanah yang terjadi di sebagian besar wilayah Cekungan Airtanah Bandung menandakan telah terjadinya pengambilan airtanah yang melebihi pengisian secara alamiah. Untuk airtanah dangkal, hampir di semua kawasan terbangun muka airtanah berada antara $3 \mathrm{~m}-20 \mathrm{~m}$ dibawah muka tanah setempat sementara pada airtanah dalam, muka airtanah berada pada kedalaman antara $15 \mathrm{~m}-91 \mathrm{~m}$ (bmt). Ini menandakan perlunya dilakukan pengimbuhan buatan. Sekitar 10,3\% atau sekitar 17,324 ha wilayah Cekungan Bandung merupakan lahan terbangun. Dengan curah hujan monsoon sekitar $1350 \mathrm{~mm} /$ tahun akan terdapat 187 juta $\mathrm{m}^{3}$ air cucuran atap yang bisa diresapkan ke dalam tanah untuk menambah potensi airtanah di Cekungan Bandung. Penerapan imbuhan buatan juga didukung oleh perundang-undangan. Sudah ada tiga peraturan yang bisa diacu untuk menerapkan imbuhan buatan di Cekungan Bandung yaitu UU No. 7 tahun 2004 tentang sumber daya air, PP No. 43 tahun 2008 tentang pengelolaan airtanah dan Perda Jawa Barat No. 16 tahun 2001 tentang airtanah.
\end{abstract}

Kata kunci: air tanah, akuifer, Cekungan Bandung, imbuhan buatan, sumur imbuhan

Naskah masuk : 14 September 2011

Naskah diterima : 8 Desember 2011

Nyoman Sumawijaya

Pusat Penelitian Geoteknologi - LIPI

E-mail : nyomans@geotek.lipi.go.id
ABSTRACT An analysis of the possibility of artificial recharge from roof top rainwater to solve the groundwater deficit in Bandung Basin has been made on the basis of the water need, water source, and regulation. Declining groundwater level in some part of the Bandung Groundwater Basin, indicated that over-pumping occur. For the shallow aquifer, about in all parts of the developed basin water level is about $3 \mathrm{~m}$ to more than $20 \mathrm{~m}$ below ground surface and for middle and deep aquifer the water level is between $15 \mathrm{~m}$ to $91 \mathrm{~m}$ below surface. This fenomena show that it is required to do artificial recharge. From about 10,3\% or 17.324 ha of developed (residential and industrial) basin area and $1350 \mathrm{~mm}$ monsoon rainfall in the Bandung Basin, about 187 million $\mathrm{m}^{3}$ water per annum can be used as source water for recharge. Application of artificial recharge to enhance groundwater potential in the Bandung Basin is supported by regulation. Government regulation No. 7 year 2004 about water resources, Government Regulation No 43, year 2008 and West Java Government regulation No. 16, year 2001 stated that it is an obligation for the developer or building owner to make and do artificial recharge.

Keywords: aquifer, artificial recharge, groundwater, Bandung Basin, recharge well.

\section{Pendahuluan}

Banjir dan kekurangan suplai air bersih merupakan masalah rutin yang dihadapi banyak kota besar di Indonesia, termasuk Bandung. Pada musim hujan terjadi banjir, sementara pada musim kemarau masyarakat kesulitan memperoleh air untuk pemenuhan kebutuhan airnya.

Untuk memenuhi berbagai keperluan masyarakat lebih kurang 317 juta $\mathrm{m}^{3} /$ tahun air tanah dangkal diambil dari Cekungan airtanah Bandung (Taufiq dkk, 2003). Jumlah pengambilan airtanah ini mungkin belum melebihi kapasitas pengisian, tetapi karena pengambilan air tanah dilakukan tidak merata di seluruh wilayah cekungan maka di 


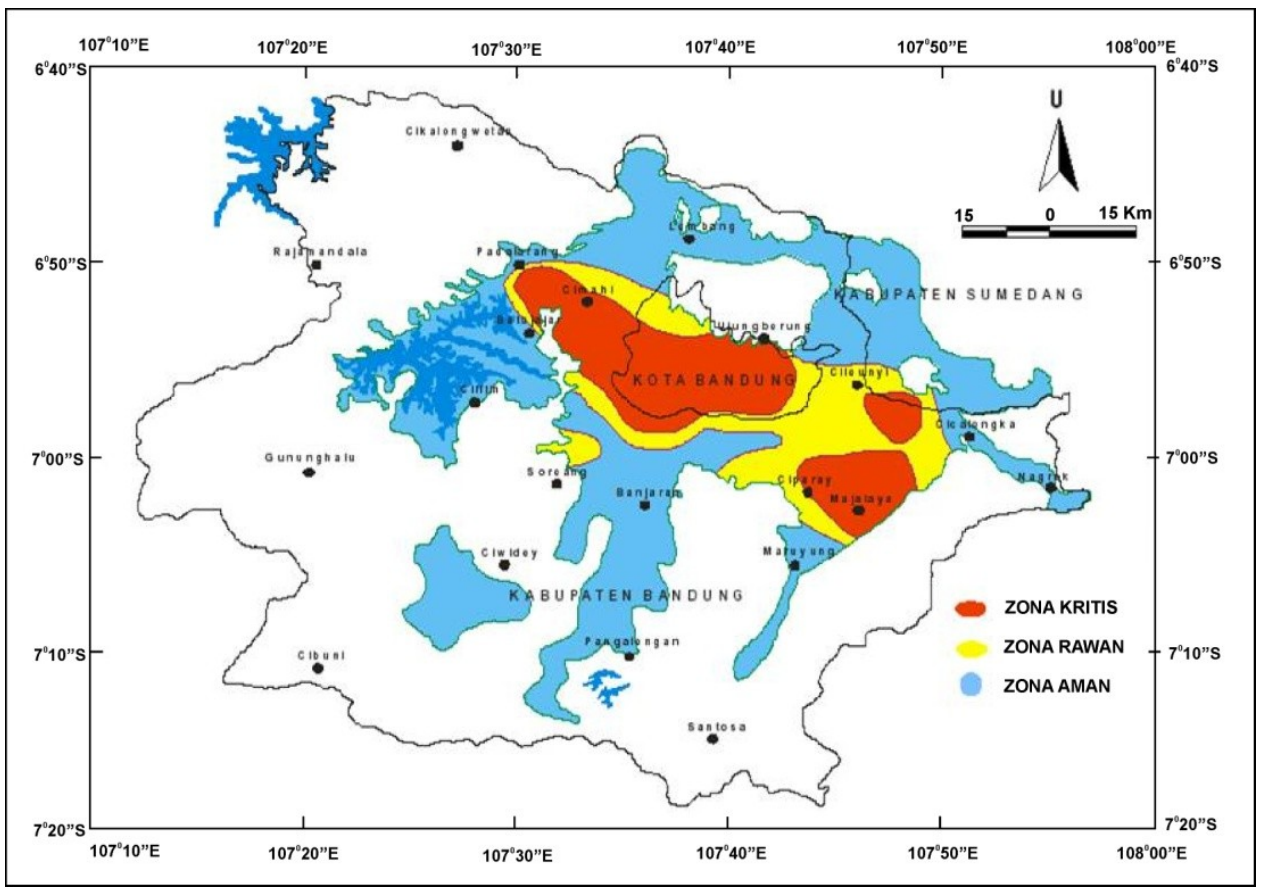

Gambar 1. Cekungan Airtanah Bandung dengan zona-zona kekritisan airtanah (Hasjim, 2006)

Tabel 1. Imbuhan Airtanah di Tiga Daerah Perkotaan di Dunia

\begin{tabular}{|c|c|c|c|c|c|c|}
\hline Kota & $\begin{array}{c}\text { Kepadatan } \\
\text { penduduk } \\
\text { (jiwa/ha) }\end{array}$ & $\begin{array}{l}\text { Curah hujan } \\
\text { (mm/tahun) }\end{array}$ & $\begin{array}{l}\text { Imbuhan air } \\
\text { tanah pra- } \\
\text { perkotaan } \\
\text { (mm/tahun) }\end{array}$ & $\begin{array}{l}\text { Imbuhan air } \\
\text { tanah era } \\
\text { perkotaan } \\
\text { (mm/tahun) }\end{array}$ & $\begin{array}{l}\text { Peningkatan } \\
\text { imbuhan } \\
\text { airtanah }(\%)\end{array}$ & $\begin{array}{l}\text { Sumber utama } \\
\text { imbuhan airtanah }\end{array}$ \\
\hline $\begin{array}{l}\text { MERIDA } \\
\text { (Mexico) }\end{array}$ & 35 & 1000 & 100 & 600 & 600 & $\begin{array}{l}\text { a) kebocoran } \\
\text { saluran air } \\
\text { b) sistim sanitasi } \\
\text { c) pluvial drainage }\end{array}$ \\
\hline $\begin{array}{l}\text { SANTA } \\
\text { CRUZ } \\
\text { (Bolivia) }\end{array}$ & 45 & 1200 & 170 & $260-290 *)$ & $\begin{array}{l}150-170 \\
150-170\end{array}$ & $\begin{array}{l}\text { a) kebocoran } \\
\text { saluran } \\
\text { b) sistim sanitasi } \\
\text { c) pluvial drainase }\end{array}$ \\
\hline $\begin{array}{l}\text { HAT YAI } \\
\text { (Thailand) }\end{array}$ & 140 & 1900 & 180 & $240 *)$ & $\begin{array}{l}130 \\
130\end{array}$ & $\begin{array}{l}\text { a) kebocoran } \\
\text { saluran air } \\
\text { b) air limbah yang } \\
\text { dibuang ke tanah }\end{array}$ \\
\hline
\end{tabular}

*) tidak termasuk kebocoran dari saluran air permukaan (sumber : Soetrisno, (1995)

sejumlah bagian cekungan telah terjadi overpumping yang ditandai dengan terjadinya penurunan muka airtanah. Di sejumlah kawasan seperti Margaasih, Cimahi Selatan, Dayeuhkolot muka airtanah dangkal berada lebih dari $10 \mathrm{~m}$ di bawah muka tanah setempat (bmt) sehingga banyak masyarakat yang harus memperdalam sumur dan mengganti pompa dengan jenis Jetpump (menambah biaya). Penurunan muka air tanah juga terjadi pada airtanah akuifer tengah dan akuifer dalam. Pada daerah padat industri seperti Dayeuhkolot, Rancaekek dan Cimahi Selatan muka airtanah berkisar antara $15 \mathrm{~m} \mathrm{~s} / \mathrm{d} 91 \mathrm{~m} \mathrm{bmt}$ (lihat Tabel 3). Hasil pemantauan Dinas
Pertambangan Jawa Barat (Hasjim, 2006) menyatakan bahwa di beberapa bagian Cekungan Bandung, kondisi air tanah sudah termasuk katagori kritis (lihat Gambar 1). Untuk menjamin ketersediaan air secara berkelanjutan perlu dilakukan upaya meningkatkan ketersediaan airtanah. Salah satu upaya yang dapat dilakukan adalah dengan melakukan imbuhan buatan dan salah satunya adalah menggunakan air cucuran atap.

Imbuhan buatan sudah lama diterapkan dibanyak tempat untuk meningkatkan ketersediaan airtanah. Kumar dan Aiyagari (1997) melaporkan sejumlah 
proyek imbuhan buatan di sejumlah Negara bagian di India. Israel dilaporkan telah menerapkan imbuhan buatan (injection wells) sejak tahun 1956 (http://www.waterencyclopedia.com/A-Bi/Artifici al-Recharge.html\#ixzz1WfUi4gbw). Imbuhan buatan juga banyak diterapkan di sejumlah negara bagian di Amerika seperti di Florida, Arizona, and California, Los Angeles County. Masyarakat Wildwood, New Jersey, sejak tahun 1968 membuat 4 sumur injeksi yang mampu mengimbuhkan air sebanyak 308 miliar liter per tahun dan berhasil dipompa kembali sebanyak 300 miliar liter/tahun. (http://www. waterencyclopedia. com/A-Bi/Artificial-Recharge.html\#ixzz1WfUi4gb $\mathrm{w})$.

Pengembangan perkotaan tidak selalu diikuti oleh penurunan potensi airtanah. Hasil penelitian Foster dkk. (1993) pada 3 kota di dunia (Tabel 1) sebagaimana dikutip Soetrisno (1995) menujukkan bahwa pembangunan perkotaan yang diikuti dengan pengelolaan air yang baik justru meningkatkan ketersediaan airtanah dibandingkan kondisi sebelum pembangunan.

Tulisan ini mencoba menganalisis prospek penerapan imbuhan buatan dengan memanfaatkan air hujan cucuran atap untuk mengatasi permasalahan defisit airtanah di Cekungan Bandung. Analisa prospek penerapan imbuhan buatan menggunakan air cucuran atap untuk mengatasi permasalahan defisit airtanah di Cekungan Bandung dilakukan berdasarkan aspek kebutuhan, adanya sumber air dan adanya dukungan kebijakan.

\section{METODOLOGI}

Pengimbuhan buatan (artificial recharge) merupakan suatu upaya manusia untuk memasukkan air permukaan ke dalam akuifer untuk menjamin keberlanjutan ketersediaan airtanah. Jika dilakukan secara masal, pengimbuhan buatan juga dapat mengurangi potensi banjir. Berbagai cara pengimbuhan dapat dilakukan seperti dengan kolam peresapan, paritan (ditches), sumur imbuhan (sumur gali atau sumur bor), sumur injeksi dll. Sementara sebagai sumber air untuk diimbuhkan dapat berupa air hujan cucuran atap, air larian (run off) dan air buangan (diolah lebih dulu). Imbuhan buatan dengan menggunakan air cucuran atap mempunyai kelebihan dibandingkan menggunakan sumber lainnya karena airnya relatif masih bersih (bebas pencemaran).

Tabel 2. Karakteristik, akuifer Cekungan Airtanah Bandung - Soreang (sumber : Wibowo dan Poeryanto, 1995)

\begin{tabular}{lccc}
\hline & \multicolumn{3}{c}{ Karakteristik akuifer (rata-rata) } \\
\cline { 2 - 4 } Formasi Batuan & Kelulusan (K: m/hari ) & Ketebalan (D), m & $\begin{array}{c}\text { Transmisivitas (T), } \\
\mathbf{~ m}^{\mathbf{2}} / \mathbf{h a r i}\end{array}$ \\
\hline F. Cikapundung & 4,77 & 130 & 212 \\
\hline F. Cibeureum & 7,5 & $10-100$ & 578 \\
\hline F. Kosambi & 5,47 & $2-20$ & 150 \\
\hline
\end{tabular}




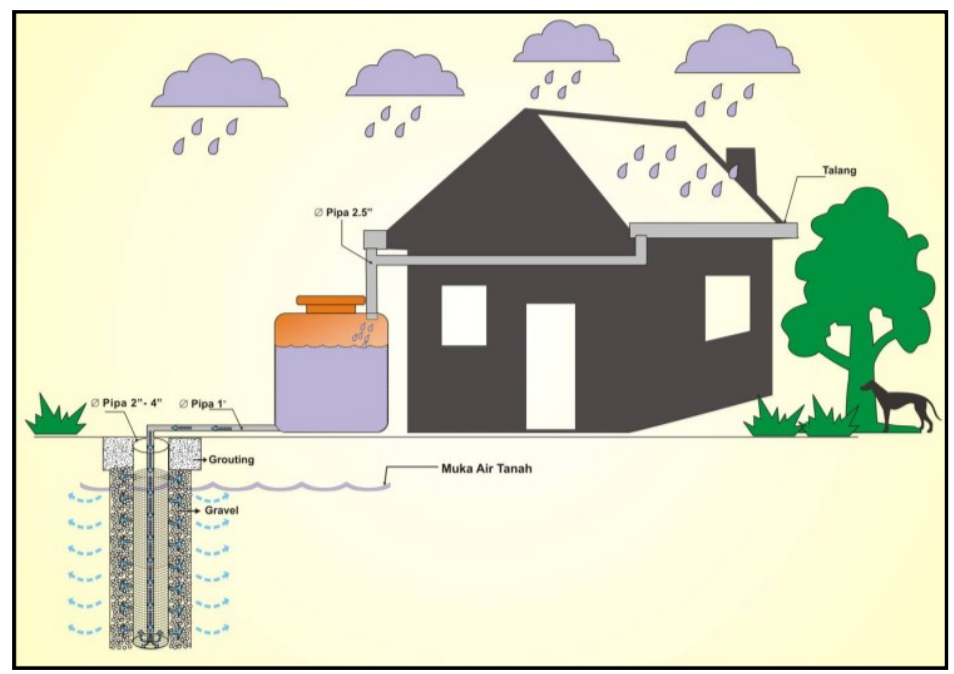

Gambar 2 : Model imbuhan buatan dengan air hujan cucuran atap (roof top rainwater harvesting).

Pengimbuhan air hujan cucuran atap ke dalam koordinat UTM 91.98.410 - 92.46.565 Utaraakuifer dapat dilakukan dengan menampung air hujan cucuran atap melalui talang dan menampungnya (sementara) dalam bak penampungan dan kemudian diresapkan kedalam tanah melalui sumur resapan (lihat Gambar 2) baik sumur gali maupun sumur bor. Teknis pembuatan sumur imbuhan sama dengan pembuatan sumur produksi. Bak penampungan diperlukan karena tidak selalu kecepatan akumulasi air hujan sama dengan kecepatan peresapan. Besarnya kapasitas tangki tampungan adalah jumlah curah hujan dari luasan atap yang ada dikurangi besarnya peresapan selama waktu hujan.

Ada tiga hal yang menjadi pertimbangan dalam melakukan imbuhan buatan: adanya kebutuhan (defisit air tanah), adanya sumber air, dan adanya dukungan kebijakan (adanya peraturan yang memungkinkan dilakukannya pengimbuhan buatan airtanah). Oleh karena itu maka analisis prospek penerapan imbuhan buatan air cucuran atap untuk meningkatkan ketersediaan airtanah di wilayah Cekungan Bandung dianalisis berdasarkan aspek kebutuhan (terjadinya penurunan muka air tanah), adanya sumber air untuk diimbuhkan dan juga adanya kebijakan ( perundangan-undangan).

\section{Lokasi}

Obyek bahasan adalah Cekungan Airtanah Bandung, yang secara administratif, mencakup seluruh wilayah Kab. Bandung, Kota Bandung dan Kota Cimahi, sebagian Kab. Sumedang, serta sebagian kecil wilayah Kab. Garut, Jawa Barat. Secara geografis, daerah kajian terletak pada Selatan dan 07.62.740 - 08.26.309 Barat-Timur, dengan luas area sekitar 168.200 ha (Gambar 1).

\section{HASIL DAN PEMBAHASAN}

\section{Kebutuhan}

Kebutuhan terhadap perlunya melakukan imbuhan buatan dilihat dari data potensi air tanah dan pengambilan air tanah. Pengimbuhan buatan diperlukan jika pengambilan airtanah melebihi jumlah pengisian alamiah yang ditandai dengan adanya penurunan muka airtanah.

\section{Potensi Airtanah}

Potensi air tanah suatu kawasan ditentukan oleh kondisi iklim, geologi (akuifer), dan pengambilan air tanah. Iklim di Cekungan Airtanah Bandung ditandai dengan musim hujan yang jatuh antara bulan Oktober - April dan musim kemarau berlangsung antara Mei - September. Curah hujan tahunan berkisar antara $1800 \mathrm{~mm}-3500 \mathrm{~mm}$ dan evapotranspirasi berkisar antara $1300 \mathrm{~mm}-1500$ $\mathrm{mm}$. Sementara litologi cekungan airtanah Bandung seperti diuraikan Wibowo dan Poeryanto (1995), Soetrisno S, (1983), terdiri dari endapan kuarter berupa batuan produk gunung api tua (Formasi Cikapundung), hasil gunung api muda (Formasi Cibereum), Formasi Cikidang, Formasi Kosambi dan endapan Kolluvium. Batuan yang berfungsi sebagai akuifer adalah Formasi Cikapundung, Formasi Cibeureum dan Formasi Kosambi dengan karakteristik seperti tertera pada Tabel 2. 


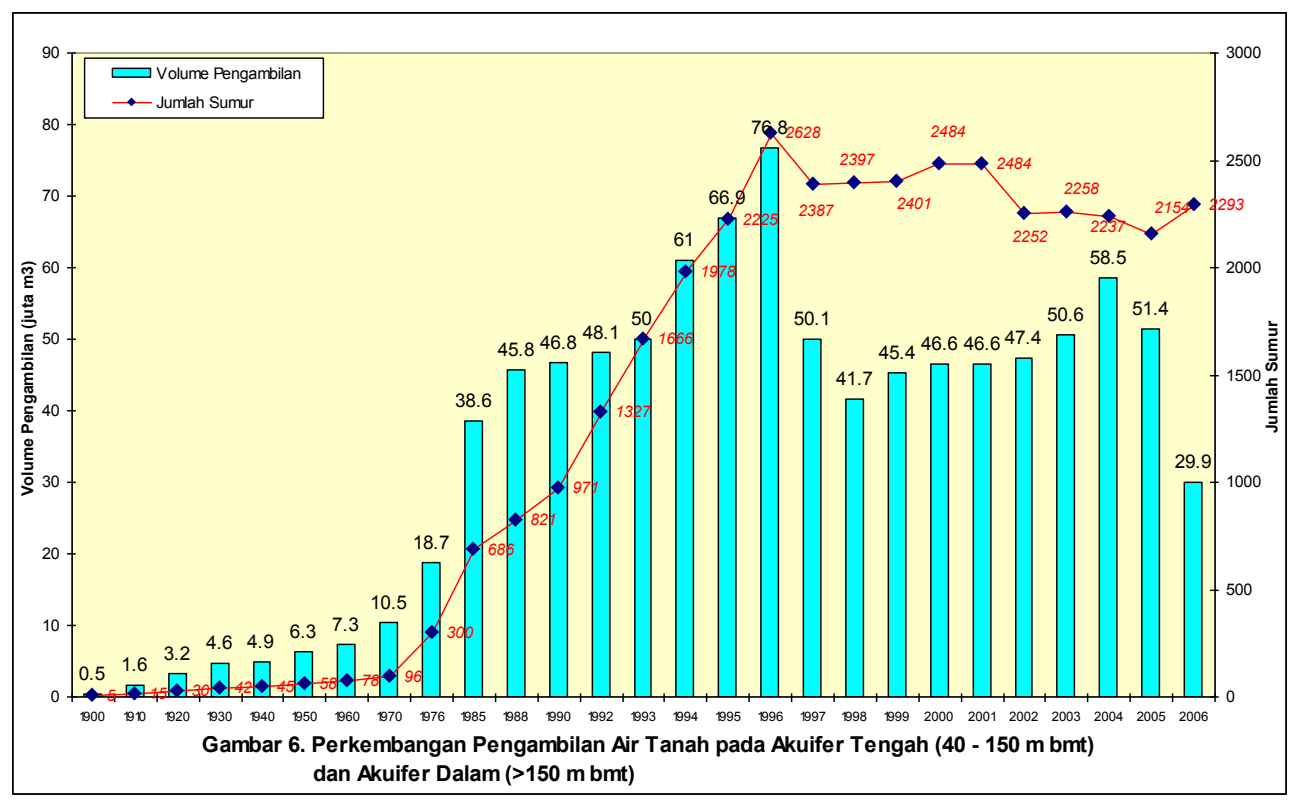

Gambar 3 : Jumlah sumur dan volume pengambilan airtanah dari akuifer tengah dan akuifer dalam ( Suryana, dkk, 2006).

Airtanah teridentifikasi berada pada akuifer air tanah dangkal (kedalaman kurang dari 40 meter) dan akuifer airtanah tengah (40 - 150 meter) serta akuifer dalam (kedalaman $>150 \mathrm{~m}$ ). Belum ada angka yang pasti mengenai potensi airtanah Cekungan Bandung ini. Berbagai sumber mengeluarkan angka yang berbeda. Berdasarkan luas wilayah, geologi penyusun dan iklim daerah
Bandung, Syaiful R. dan Sukrisna A, (2000) sebagaimana dikutip Taufiq dkk (2003) menyatakan imbuhan airtanah dangkal di Cekungan Bandung adalah 368,5 juta $\mathrm{m}^{3} /$ tahun. Sementara Haryadi \& Schmidt, (1991) sebagaimana dikutip Taufiq dkk (2003) berdasarkan model aliran air tanah memperkirakan volume aliran airtanah tengah dan dalam sekitar 117 juta $\mathrm{m}^{3} /$ tahun.

Tabel 3. Kedudukan Muka Airtanah pada Akuifer Tengah dan dalam.

\begin{tabular}{|c|c|c|c|c|}
\hline No & Daerah & $\begin{array}{l}\text { MAT Awal } \\
{[\mathrm{m} \mathrm{bmt}]}\end{array}$ & $\begin{array}{c}\text { MAT } \\
\text { Th 2000 } \\
{[\mathrm{m} \text { bmt }]} \\
\end{array}$ & $\begin{array}{c}\text { MAT } \\
\text { Th 2006 } \\
{[\mathrm{m} \text { bmt }]}\end{array}$ \\
\hline 1. & Padalarang & 15,77-26,10 (Th.1999) & $15,77-26,10$ & $22,59-32,62$ \\
\hline 2. & Cimahi Utara & 75,15, (Th. 1998) & 75,15 & $45,82-76,85$ \\
\hline 3. & Cimahi Selatan & $25,87-55,51,($ Th. 1994) & $31,25->100$ & $41,6-90,4$ \\
\hline 4. & Margaasih & $\begin{array}{l}24,86-69,24(T h .1999- \\
2001)\end{array}$ & $20,12-67,13$ & $26,6-41,2$ \\
\hline 5. & Ujungberung, Cibiru & $16,46-20,10,($ Th. 1994) & $12,66-33,16$ & $11,56-23,17$ \\
\hline 6. & Cileunyi & & $12,66-33,16$ & $1,12-22,85$ \\
\hline 7. & Dayeuhkolot & $21,89-58,15$ (Th. 1994) & $12,68-83,46$ & $25,5-62,08$ \\
\hline 8. & Baleendah & 13,67 (Th. 1996) & $15,92-45,70$ & $6,19-24,5$ \\
\hline 9. & Ketapang, Soreang & $\begin{array}{l}7,45-19,44(\text { Th. } 1992- \\
1994)\end{array}$ & $5,95-26,53$ & $8,25-47,60$ \\
\hline 10. & Majalaya, Ciparay & $16,60-47,35,($ Th. 1996) & $9,99-56,17$ & $2,8-40,92$ \\
\hline 11. & Cicalengka & $4,70-5,75($ Th. 1989) & $4,20-35,57$ & $6,29-29,82$ \\
\hline
\end{tabular}

Sumber : (diolah dari Suryana dkk, 2006). 
Pengambilan Airtanah dan Penuruan Muka Airtanah

\section{Airtanah Dangkal}

Pengambilan airtanah dangkal terutama dilakukan oleh masyarakat untuk pemenuhan kebutuhan air rumah tangga. Sangat sulit mendapatkan data tentang jumlah pengambilan airtanah dangkal karena tidak ada sistem pendataan yang dilakukan. Angka jumlah pengambilan airtanah dangkal diperkirakan berdasarkan jumlah kebutuhan air bersih dikurangi pasokan air PDAM. Untuk tahun 2005 misalnya, berdasarkan data jumlah penduduk dan asumsi kebutuhan air perkapita, Suryana (2006) memperkirakan kebutuhan air rumahtangga di Cekungan Bandung sebesar $354 \times 10^{6} \mathrm{~m}^{3} /$ tahun, sementara kemampuan PDAM Kota dan Kab Bandung yang mencakup wilayah pelayanan Kota dan Kab. Bandung, dan Kota Cimahi mencapai 36,5 juta $\mathrm{m}^{3} /$ tahun sehingga jumlah pengambilan airtanah diperkirakan $317,5 \times 10^{6} \mathrm{~m}^{3} /$ tahun .

Kalau dilihat dari jumlah pengambilan $\left(317,5 \times 10^{6}\right.$ $\mathrm{m}^{3} /$ tahun) dibandingkan perkiraaan pengimbuhan (368,5 juta $\mathrm{m}^{3} /$ tahun) masih lebih besar pengimbuhan. Namun perlu diperhatikan bahwa pengambilan air tanah terkonsentrasi pada lahan terbangun yang luasnya hanya $10,3 \%$ sampai $11,9 \%$ dari seluruh luas cekungan maka pengambilan telah berdampak pada penurunan muka air tanah.

Hampir di seluruh kawasan permukiman di Cekungan Bandung ini telah terjadi penurunan muka airtanah dangkal. Berdasarkan hasil survei, Suryana dkk (2006) melaporkan kedudukan muka air tanah dangkal di wilayah Cekungan Bandung antara $3 \mathrm{~m}$ bawah muka tanah setempat (bmt) sampai $20 \mathrm{~m}$ bmt seperti di daerah Dayeuhkolot, Cileunyi, Cikeruh, Cibeunying Kidul dan Sukajadi. Di sejumlah wilayah yang penurunan air tanahnya cukup besar, masyarakat sudah tidak mungkin menggunakan pompa isap biasa, mereka harus menambah kedalaman sumur dan mengganti jenis pompa dengan pompa tekan (Jetpump) (menambah biaya pengadaan air).

\section{Airtanah pada Akuifer Tengah dan Dalam}

Air tanah tengah $(>40-150 \mathrm{~m})$ dan dalam (kedalaman $>150 \mathrm{~m}$ ) terutama dimanfaatkan oleh industri, PDAM dan perkantoran. Oleh karena itu perkembangan pengambilan airtanah pada akuifer tengah dan dalam sangat dipengaruhi oleh perkembangan industri di wilayah Bandung Soreang. Pada Gambar 3 diperlihatkan data perkembangan jumlah sumur dan volume pengambilan airtanah dari akuifer tengah dan dalam.

Seperti airtanah dangkal, pengambilan airtanah tengah dan dalam juga sudah melebihi kemampuan pengisian yang ditandai terjadinya penuruan muka airtanah (lihat Tabel 3 dan Gambar 1). Berdasarkan hasil perhitungan dengan menggunakan model F.J. Mock, Budi Fachrudin (1996), menyatakan bahwa untuk kondisi tahun 1994 saja telah terjadi defisit airtanah di cekungan Bandung sebesar 16.28 juta $\mathrm{m}^{3}$ per tahun sehingga berdampak pada penurunan muka airtanah.

Sebagaimana terlihat pada Tabel 3, muka airtanah pada akuifer tengah dan dalam di sejumlah kawasan, terutama kawasan industri sudah berada lebih dari 50 meter dibawah muka tanah setempat, bahkan ada yang sudah mencapai 91 meter seperti di daerah Cimahi selatan.

Kalau dilihat dari jumlah sumur, mulai tahun 1996 sampai 2006 jumlahnya relatif tetap tetapi volume pengambilan airtanah terus berkurang. Hal ini dapat diduga karena sejumlah sumur sudah tidak bisa berproduksi secara maksimal karena besarnya penurunan muka air tanah (head).

Dengan makin dalamnya letak muka airtanah maka daya yang dibutuhkan untuk memompa air tanah menjadi lebih besar. Selanjutnya akan menambah biaya pemompaan dan memperoleh air. Untuk menjamin keberlanjutan pasokan air bagi masyarakat (rumahtangga dan industri) maka perlu dilakukan upaya penambahan pengisian airtanah. Jika pengimbuhan buatan dapat dilakukan secara masal, selain dapat menambah ketersediaan air tanah juga dapat diharapkan mengurangi biaya pemompaan dan juga mengurangi potensi banjir.

\section{Sumber Air}

Sumber air dari air hujan cucuran atap ditentukan oleh curah hujan dan luas atap. Berdasarkan analisa data citra landsat, Narulita dkk (2008) menyatakan dari sekitar 168.200 ha luas CAT Bandung, kira-kira $10,3 \%$ atau 17,324 ha merupakan kawasan terbangun (permukiman, perkantoran dan industri). Sebelumnya Hilda (2006) juga melaporkan hasil interpretasi citra landsat bahwa untuk data tahun 2001 kira-kira $11,9 \%$ dari bagian hulu DAS Cikapundung merupakan kawasan terbangun. Air hujan cucuran 
atap bangunan yang berada di wilayah terbangun ini dapat diandalkan sebagai sumber air untuk imbuhan buatan. pengukuran Ujung Berung dan stasiun pengukuran Bandung (BMKG Kelas II Jl Cemara), untuk kurun waktu antara tahun 2003 s/d 2007, curahan

Tabel 4. Curah hujan, luas atap dan volume air hujan tertampung

\begin{tabular}{|c|c|c|c|c|c|c|c|c|c|c|c|c|c|c|}
\hline $\begin{array}{c}\text { Luas } \\
\text { atap }\end{array}$ & \multicolumn{10}{|c|}{ Curah hujan ( mm) } \\
\hline (m2.) & 100 & 200 & 300 & 400 & 500 & 600 & 800 & 1000 & 1200 & 1400 & 1600 & 1800 & 2000 \\
\hline & \multicolumn{10}{|c|}{ Volume air (m3) } \\
\hline 20 & 1.6 & 3.2 & 4.8 & 6.4 & 8 & 9.6 & 12.8 & 16 & 19.2 & 22.4 & 25.6 & 28.8 & 32 \\
\hline 30 & 2.4 & 4.8 & 7.2 & 9.6 & 12 & 14.4 & 19.2 & 24 & 28.8 & 33.6 & 38.4 & 43.2 & 48 \\
\hline 40 & 3.2 & 6.4 & 9.6 & 12.8 & 16 & 19.2 & 25.6 & 32 & 38.4 & 44.8 & 51.2 & 57.6 & 64 \\
\hline 50 & 4 & 8 & 12 & 16 & 20 & 24 & 32 & 40 & 48 & 56 & 64 & 72 & 80 \\
\hline 60 & 4.8 & 9.6 & 14.4 & 19.2 & 24 & 28.8 & 38.4 & 48 & 57.6 & 67.2 & 76.8 & 86.4 & 96 \\
\hline 70 & 5.6 & 11.2 & 16.8 & 22.4 & 28 & 33.6 & 44.8 & 56 & 67.2 & 78.4 & 89.6 & 100.8 & 112 \\
\hline 80 & 6.4 & 12.8 & 19.2 & 25.6 & 32 & 38.4 & 51.2 & 64 & 76.8 & 89.6 & 102.4 & 115.2 & 128 \\
\hline 90 & 7.2 & 14.4 & 21.6 & 28.8 & 36 & 43.2 & 57.6 & 72 & 86.4 & 100.8 & 115.2 & 129.6 & 144 \\
\hline 100 & 8 & 16 & 24 & 32 & 40 & 48 & 64 & 80 & 96 & 112 & 128 & 144 & 160 \\
\hline 150 & 12 & 24 & 36 & 48 & 60 & 72 & 96 & 120 & 144 & 168 & 192 & 216 & 240 \\
\hline 200 & 16 & 32 & 48 & 64 & 80 & 96 & 128 & 160 & 192 & 224 & 256 & 288 & 320 \\
\hline 250 & 20 & 40 & 60 & 80 & 100 & 120 & 160 & 200 & 240 & 280 & 320 & 360 & 400 \\
\hline 300 & 24 & 48 & 72 & 96 & 120 & 144 & 192 & 240 & 288 & 336 & 384 & 432 & 480 \\
\hline 400 & 32 & 64 & 96 & 128 & 160 & 192 & 256 & 320 & 384 & 448 & 512 & 576 & 640 \\
\hline 500 & 40 & 80 & 120 & 160 & 200 & 240 & 320 & 400 & 480 & 560 & 640 & 720 & 800 \\
\hline 1000 & 80 & 160 & 240 & 320 & 400 & 480 & 640 & 800 & 960 & 1120 & 1280 & 1440 & 1600 \\
\hline
\end{tabular}

Dalam perencanaan imbuhan buatan, biasanya yang diperhitungakan adalah air hujan yang jatuh pada musim hujan (monsoon) yaitu hujan yang jatuh antara Oktober sampai April. Hujan yang jatuh pada musim kemarau biasanya intensitasnya rendah sehingga tidak efektif untuk pengimbuhan. Berdasarkan data curah hujan di stasiun hujan musim hujan berkisar antara $1300 \mathrm{~mm}$ sampai $1400 \mathrm{~mm}$, (rata-rata $1350 \mathrm{~mm}$ ).

Jumlah air hujan yang bisa ditampung $(\mathrm{V})=$ luas atap $\left(\mathrm{m}^{2}\right.$.) dilakukan rata-rata curah hujan $(\mathrm{m}) \mathrm{x}$ 0,8 . Angka 0,8 dipakai sebagai tetapan yang menyatakan perbandingan antara jumlah air hujan yang bisa ditampung dengan jumlah curah hujan

Tabel 5 : Data teknis sumur imbuhan di kota Cimahi

\begin{tabular}{|c|c|c|c|c|c|c|c|}
\hline No & Diameter & $\begin{array}{c}\text { Kedalaman } \\
\text { / panjang } \\
\text { screen }\end{array}$ & $\begin{array}{l}\text { Litologi } \\
\text { akuifer }\end{array}$ & $\begin{array}{r}\text { Luas atap } \\
\text { dipasangi } \\
\text { talang }\left(\mathrm{m}^{2}\right)\end{array}$ & $\begin{array}{c}\text { Volume air } \\
\text { tertampung } \\
\text { selama } 2 \text { jam } \\
\text { (liter) }\end{array}$ & $\begin{array}{l}\text { Kemampuan } \\
\text { Peresapan } \\
\text { selama } 2 \text { jam } \\
\text { (liter) }\end{array}$ & $\begin{array}{c}\text { Tangki } \\
\text { penampung } \\
\text { yang } \\
\text { dibutuhkan }\end{array}$ \\
\hline 1 & 4 inci & $28 \mathrm{~m} / 8 \mathrm{~m}$ & $\begin{array}{c}\text { Pasir - } \\
\text { pasir } \\
\text { lempungan }\end{array}$ & 100 & 2240 & 1152 & 1088 \\
\hline 2 & 4 inci & $28 \mathrm{~m} / 8 \mathrm{~m}$ & $\begin{array}{c}\text { Pasir } \\
\text { sedang - } \\
\text { pasir } \\
\text { lempungan }\end{array}$ & 30 & 672 & 1152 & 0 \\
\hline 3 & 4 inci & $28 \mathrm{~m} / 8 \mathrm{~m}$ & $\begin{array}{c}\text { Pasir - } \\
\text { pasir } \\
\text { lempungan }\end{array}$ & 45 & 1008 & 1152 & 0 \\
\hline
\end{tabular}


yang sebenarnya (SNI 03-2453-2002). Dengan rata-rata curah hujan musim hujan $1350 \mathrm{~mm}$ maka jumlah air hujan yang dapat tertampung untuk diimbuhkan dari kawasan permukiman seluas 17.324 ha adalah :

$\mathrm{V}=17.324$ ha $\times 10.000 \mathrm{~m} 2 / \mathrm{ha} \times 1350 \mathrm{~mm}$ hujan/tahun $\times 0.001 \mathrm{~m} / \mathrm{mm} \times 0,8=187.105 .680$ $\mathrm{m}^{3} /$ tahun. Sementara jumlah air hujan yang dapat ditampung dan diimbuhkan kedalam tanah dari tiap bangunan tergantung dari luas atap ( Tabel 4).

Jika diasumsikan 50\% dari kawasan terbangun adalah berupa atap bangunan yang ditampung air cucuran atapnya maka air yang potensial untuk diresapkan adalah $93,552,840 \mathrm{~m}^{3}$ per tahun; hampir sama dengan 30\% dari perkiraan jumlah pengambilan airtanah yang selama ini berlangsung. Jumlah pengisian airtanah dengan imbuhan buatan di kawasan permukiman ini jauh lebih besar dibandingkan dengan jumlah peresapan alamiahnya. Dengan menggunakan asumsi dari Fleming (1975) Lubis (1995) menyatakan bahwa besarnya imbuhan airtanah secara alamiah dari air hujan di Indonesia adalah sekitar (8\% - 15\%). Berdasarkan angka ini maka besarnya imbuhan alamiah pada area yang dikonversikan menjadi areal terbangun di CAT Bandung adalah 18,7 juta $\mathrm{m}^{3} \mathrm{~s} / \mathrm{d} 35$ juta $\mathrm{m}^{3}$ per tahun. Dari skenario ini dapat dilihat bahwa alih fungsi lahan menjadi areal terbangun (kawasan perumahan, perkantoran dan industri); jika dikuti dengan penerapan imbuhan buatan tidak akan menurunkan pengimbuhan air tanah; dan juga tidak akan menambah air larian.

Untuk pemulihan kondisi airtanah di CAT Bandung, Djuwansah dkk (2008) mengusulkan pembatasan pengambilan airtanah hanya $50 \%$ dari kapasitas infiltrasi atau penghentian pengambilan airtanah. Secara teoritis cara ini akan dapat mengembalikan kondisi airtanah, namun sulit untuk dilaksanakan karena kebutuhan air yang tetap tinggi sementara kemampuan PDAM untuk menyediakan air bagi masyarakat masih rendah. Selain itu, dengan pembatasan pengambilan airtanah hanya mampu menjaga potensi airtanah, tetapi tidak memecahkan masalah pemenuhan kebutuhan air dan potensi banjir. Sementara dengan imbuhan buatan, potensi airtanah dapat ditingkatkan, masalah pemenuhan kebutuhan air teratasi dan potensi banjir bisa dikurangi.

\section{Hasil Uji Pengimbuhan}

Dalam rangka mengimplementasikan teknologi pengolahan di tempat (in-ground treatment) air tanah yang mengandung ion besi dan mangan melebihi ambang batas (Sumawijaya dkk, 2010) telah dibuat 3 sumur imbuhan di komplek perumahan Nusa Hijau, Cimahi (Tabel 5). Untuk mengetahui kapasitas pengimbuhan sumur dilakukan pengujian dengan metode kocoran. Dalam metode ini air sebanyak 500 lt diimbuhkan ke dalam sumur. Selama pengimbuhan, muka air di dalam sumur dipertahankan tetap (konstan head) dengan cara mengatur kecepatan pengimbuhan melalui kran (valve). Hasil uji pengisian dengan kocoran diperoleh kapasitas peresapan rata - rata $0,16 \mathrm{lt} / \mathrm{dt}$ atau $1152 \mathrm{lt} / 2 \mathrm{jam}$ (lihat Table 5).

Peresapan dapat berlangsung secara terus menerus selama ada pasokan air dan ruang yang dapat diisi sedangkan durasi curah hujan dan intensitasnya tidak bisa ditentukan. Tidak semua air hujan bisa secara langsung dimasukkan ke dalam akuifer (diimbuhkan). Untuk memaksimalkan air hujan yang dapat diresapkan maka instalasi imbuhan buatan perlu dilengkapi tangki penampungan. Sebelum air hujan dimasukkan ke dalam sumur imbuhan ditampung dulu dalam tangki penampungan (Gambar 2). Selain untuk menampung selisih air hujan yang terakumulasi selama waktu hujan dengan kecepatan peresapan, tangki penampungan juga berfungsi untuk menyaring kotoran yang turut terbawa bersama air hujan cucuran atap.

Untuk menentukan dimensi, jumlah sumur dan tangki penampungan untuk luas atap dan jenis akuifer tertentu diperlukan data intensitas hujan ( curah hujan 1 jam). Berdasarkan data hasil pengukuran curah hujan yang dipasang di lokasi percobaan sejak Februari 2010 curah hujan harian maksimum yang terukur adalah $70 \mathrm{~mm}$. Biasanya durasi hujan yang digunakan untuk perencanaan imbuhan buatan adalah selama 2 jam. Menurut Sosrodarsono dan Takeda (1987) untuk curah hujan periode 2 jam besarnya $32 \%$ dari curah hujan harian, sehingga curah hujan 2 jam di kota Cimahi adalah $22.40 \mathrm{~mm}$. Dengan demikian maka untuk waktu hujan lebat yang diasumsikan selama 2 jam volume air tertampung dan jumlah peresapan adalah seperti disajikan pada Tabel 5. Dari table ini dapat dilihat, untuk sumur no 2 dan 3, karena luas atap sebagai penyuplai air hujan relatif kecil jumlah air hujan lebih kecil dari kapasitas 
peresapan sehingga tidak diperlukan tangki penampungan.

Jika satu keluarga yang terdiri dari 4 orang ( suami istri dan 2 anak), rata-rata pemakaian air 125 1t/or/hari maka kebutuhan air selama 1 tahun = $182,5 \mathrm{~m}^{3}$. Dari data pada Tabel 5 dan Tabel 4 dapat dilihat bahwa jika luas atap rumahnya $100 \mathrm{~m}^{2}$ maka dari curah hujan $1350 \mathrm{~mm} /$ tahun akan tertampung dan diimbuhkan air hujan sebanyak $112 \mathrm{~m}^{3}$, sama dengan $61 \%$ kebutuhan keluarga tersebut selama 1 tahun. Dari analisis ini dapat dilihat bahwa jika air cucuran atap dapat diimbuhkan ke dalam akuifer maka akan dapat menggantikan sekitar $61 \%$ dari jumlah air tanah yang diambil oleh satu keluarga dengan 4 orang anggota.

\section{Aspek Hukum Penerapan Imbuhan Buatan}

Berkenaan dengan aspek hukum dan kewajiban masyarakat dalam melakukan pengimbuhan airtanah, ada 3 peraturan perundang-undangan yang bisa diacu oleh Pemerintah Daerah sebagai landasan hukum untuk mewajibkan penerapan imbuhan buatan di Cekungan Airtanah Bandung.

Pertama, UU No 7 tahun 2004 yang menggariskan bahwa pengelolaan sumber daya air, termasuk airtanah harus secara lestari. Salah satu cara untuk menjaga agar sumber daya airtanah tetap lestari adalah meningkatkan pengisian airtanah dengan teknik imbuhan buatan. Kedua, PP No 43 tahun 2008 tentang airtanah, khususnya pasal 40 ayat 3 huruf (c) yang menyatakan bahwa salah satu cara yang dapat dilakukan untuk memulihkan airtanah yang dalam kondisi kritis adalah dengan melakukan imbuhan buatan. Landasan yang ketiga adalah Peraturan Daerah Propinsi Jawa Barat No. 16 tahun 2001 tentang Pengelolaan Air Bawah Tanah. Pasal 7 huruf (e) Perda No. 16 tahun 2001 ini menyatakan bahwa Pemegang izin mendirikan bangunan berkewajiban membuat sumur resapan.

Kalau dilihat dari jumlahnya, mungkin sudah cukup tersedia aturan tentang pembuatan sumur imbuhan. Tetapi ternyata sampai sekarang keterlibatan masyarakat masih rendah. Belum banyaknya masyarakat membuat sumur imbuhan diduga karena aturan yang ada belum bersifat memaksa. Masih semacam himbauan; belum ada sangsi bagi yang tidak melakukannya.

Dalam pasal 84 UU No. 7 tahun 2004 tentang Sumber Daya Air dinyatakan bahwa ketentuan tentang keterlibatan masyarakat dalam pengelolaan sumber daya air diatur lebih lanjut dengan peraturan pemerintah. Sampai saat ini belum ada PP tersebut. Demi mewujudkan terjadinya pengelolaan sumber daya air yang baik perlu segera dibuat/dikeluarkan PP yang mengatur tentang keterlibatan masyarakat dalam pengelolaan sumber daya air. Secara tradsional, masyarakat kita sudah terbiasa melakukan upaya konservasi sumber daya air (khususnya di pedesaan). Masyarakat Nusa Tenggara Barat dan Nusa Tenggara Timur sudah lama mempraktekkan teknik embung untuk meningkatkan ketersediaan air untuk pemenuhan kebutuhannya. Budaya seperti ini seharusnya bisa juga dilembagakan di perkotaan, seperti di perkotaan pada wilayah Cekungan Bandung. Namun karena masyarakat perkotaan sudah cenderung individualis dan kesadaran lingkungannya relatif kurang maka perlu dilakukan pengaturan.

Air adalah kebutuhan pokok bagi manusia dan lingkungan yang tingkat ketersediaannya; khususnya di wilayah perkotaan sudah banyak bermasalah; bahkan di beberapa lokasi sudah pada tingkat kritis maka peran semua pihak, termasuk masyarakat perlu digalakkan. Melalui pengaturan oleh pemerintah; terlebih dengan adanya sistem penghargaan dan penalti bagi yang tidak melaksanakan kewajibannya maka peran masyarakat untuk memulihkan kondisi air tanah di Cekungan Bandung akan terwujud. Dalam peraturan presiden No. 33 tahun 2011 tentang kebijakan Nasional Pengelolaan Sumber Daya Air sudah dinyatakan perlunya memberikan insentif bagi masyarakat yang berprestasi dalam pengelolaan sumber daya air. Kiranya kebijakan ini perlu ditindaklanjuti dengan aturan yang bersifat teknis sehingga bisa diopersionalkan. Aturan atau petunjuk teknis yang dibuat harus terkait dengan besarnya pengimbuhan yang harus dilakukan oleh pemilik bangunan dikaitkan dengan luas bangunan dan besarnya volume pengambilan air.

\section{Kesimpulan dan Saran}

Pengambilan airtanah di sejumlah wilayah Cekungan Bandung telah melebihi jumlah pengisian yang ditandai oleh penurunan muka airtanah. Dilihat dari segi kebutuhannya dan ketersediaan sumber air (air cucuran atap) penerapan imbuhan buatan dari air hujan cucuran atap sangat prospek untuk meningkatkan ketersediaan airtanah di Cekungan Aitanah 
Bandung. Jika 50\% dari atap bangunan di kawasan terbangun dapat ditampung air cucuran atapnya maka $\pm 93,552,840 \mathrm{~m}^{3} /$ tahun air hujan dapat dimasukkan ke dalam akuifer untuk menambah ketersediaan airtanah. Selain pertimbangan teknis, penerapan imbuhan buatan (sumur resapan) juga didukung oleh landasan hukum yang ada.

Untuk meningkatkan peran serta masyarakat dalam melakukan pengimbuhan buatan perlu dipertegas aturan yang ada dengan menentukan sangsi bagi yang tidak melakukannya dan memberikan penghargaan bagi mereka yang melaksanakan kegiatan melebihi kewajibannya.

\section{Ucapak terimakasih}

Terimakasi kami sampaikan kepada Ir. Agus Taufiq, Pusat Lingkungan Geologi dan Kawasan Pertambangan, Departemen ESDM yang telah banyak memberikan bahan masukan untuk penulisan ini. Terimakasih juga kami sampaikan kepada saudara Alfi Ramdani, yang telah membantu penulis dalam menyiapkan gambargambar. Terimakasih juga kami sampaikan kepada semua rekan di Puslit Geoteknologi yang telah banyak memberikan dorongan kepada penulis sehingga tulisan ini bisa diselesaikan.

\section{Daftar Psutaka}

Standar Nasional Indonesia 03-2453-2002, Tata Cara Perencanaan Sumur Resapan Air Hujan Untuk Lahan Pekarangan, Badan Standar Nasional.

Roof Top Rain Water Harvesting, http://cgwb.gov.in/GroundWater/rooftop Tabel.htm).

Undang Undang No 7 tahun 2004, Tentang Sumber Daya Air

Peraturan Pemenrintah No 43 tahun 2008 Tentang Airtanah

Peraturan Daerah Propinsi Jawa Barat No. 16 tahun 2001 tentang Pengelolaan Air Bawah Tanah

Peraturan Pemerintah RI No. 33 tahun 2011 tetang Kabijakan Nasional Pengelolaan Sumber Daya Air.

Djuwansah M.R., Delinom, R.M., Rahmat A., Narulita I., 2008, Exploitation and Recharge Estimate using Tabel Contour and Soil Moisture Balance for the
Evaluation of Groundwater Use in Bandung Basin, Proc. Int. Seminar on Groundwater Management and Related Water Resources Issues in the SEA and EA, Indonesian Institute of Sciences,

Driscoll, F.G, 1986 (Editor), Groundwater and Wells, $\left(2^{\text {nd }}\right.$ Ed $)$, Johnson Filtration Sistem Inc, Minnesota 55112

Fachrudin B., 1996, Pengelolaan Airtanah Cekungan Bandung Dengan Menggunakan Model FJ. Mock.(Abstrak), http://gdl.geoph.itb.ac.id/gdl.php?mod=br owse \&op=read\& id=jbptitbgeoph-gdls1-1996-budifachru-516

Hasjim, I. 2006., Kebijakan Pemanfaatan Airtanah di Jawa Barat, Jurnal Geoaplika, Volume 1, Nomor 3, hal. $101-110$

Kumar, N.N dan N. Aiyagari, 1997, Artificial Recharge of Groundwater, http://www. cee.vt.edi/ewr/environmental/recharge/rec harge.html

Lestiani, H., 2006, Konversi Lahan dan Pengaruhnya pada Iklim di Kota Bandung, Widyariset, Vol 9, No. 2, LIPI, Jakarta.

Lubis A, 1995, Pola Infiltrasi Air Hujan Serta Implikasinya Terhadap Konservasi Airtanah, Pros. Simp. Nasional "Pengelolaan Airtanah di Indonesia", Gugus Tugas Penelitian Sumberdaya Air ITB.

Kumar N.N dan N. Aiyagari, 1997., Artificial Rechrage of Groundwater; http://www. cec.vt.edi/ewr/envireonmental/recharge/rec harge.html diunduh Desember 2009.

Narulita,I., Rachmat, A., Maria, R., 2008, Aplikasi Sistem Informasi Geografi untuk Menentukan Daerah Prioritas Rehabilitasi di Cekungan Bandung, Jurnal Riset Geologi dan Pertambangan Jilid 18 No.1 th 2008, pp 23-35

Soetrisno, S 1995, Imbuhan Buatan dan Pembangunan di Bandung Utara, Makalah disampaikan pada Seminar Penutupan Proyek CTA - 108, Bandung, 3 Juli 1995 
Sumawijaya., Suherman D., Sudaryanto, 2010., Penerapan, Teknologi Pengolahan di Tempat (in-ground treatment) Air Tanah Tercemar Ion Besi dan Mangan di kota Cimahi, Jawa Barat, Prosiding Pemaparan Hasil Penelitian Puslit Geoteknologi LIPI, ISBN: 978-979-8636-17-2

Suryana, U., 2006, Pemantauan Kondisi Lingkungan Air Tanah di Bandung, Provinsi Jawa Barat, DEPARTEMEN ENERGI DAN SUMBER DAYA MINERAL, DIREKTORAT JENDERAL MINERAL, BATUBARA DAN PANAS BUMI, Laporan No. : 27/Lap/DPA/2006
Taufik A, 2003, Pemantauan Kondisi Lingkungan Air Tanah Cekungan Air Tanah BandungSoreang, Jawa Barat, EPARTEMEN ENERGI DAN SUMBER DAYA MINERAL, DIREKTORAT JENDERAL GEOLOGI DAN SUMBERDAYA MINERAL, Direktorat Tata Lingkungan Geologi dan Kawasan Pertambangan, Laporan No. : 18/LAP/DIPA/2003

Wibowo dan Poeryanto, 1995, Geometri Akuifer dan Potensi Airtanah Cekungan Bandung, Prosiding Seminar Airtanah Cekungan Bandung, Satgas Penelitian Sumber Daya Air, ITB, 